\title{
TITLE:
}

\section{A Potent and Site-Selective Agonist of TRPA1(Abstract_要旨)}

\section{$\operatorname{AUTHOR(S):~}$}

Takaya, Junichiro

\section{CITATION:}

Takaya, Junichiro. A Potent and Site-Selective Agonist of TRPA1. 京都大 学, 2016, 博士(医学)

\section{ISSUE DATE:}

2016-03-23

URL:

https://doi.org/10.14989/doctor.k19611

RIGHT:

許諾条件により本文は2017-03-23に公開 


\begin{tabular}{|l|c|c|r|}
\hline 京都大学 & 博士 (医学) & 氏 名 & 高 屋 潤 一 郎 \\
\hline 論文題目 & $\begin{array}{c}\text { A Potent and Site-Selective Agonist of TRPA1 } \\
\text { (TRPA1 の強力かつサイト選択的なアゴニスト) }\end{array}$ & \\
& &
\end{tabular}

（論文内容の要旨）

Transient receptor potential （TRP）ファミリーに属する TRPA1 は、化学 物質センサーの一つとして知られる。この非選択的カチオンチャネルは、多様 な反応性化合物によって活性化を受け、痛み、咳、呼吸パターンの变化などの 防衛反応を起こす。TRPA1 を活性化する反応性化合物の代表として、ワサビの 辛み成分である Allyl isothiocyanate (AITC)が知られている。TRPA1 の活性化 は、幾つかのシステイン残基への化合物による修飾が引き金となっている。し かし、どのシステイン残基への修飾が、どのようにチャネルの活性化に寄与し ているのかは明確ではなかった。

【強力かつ選択的な求電子性アゴニスト】 TRPA1 の活性化メカニズムを検証す るため、新規 TRPA1 アゴニストのスクリーニングを行った。1,657 個の求電子性化合物 をスクリーニングしたところ、3つの構造類似性を持つ強力なアゴニスト $\left(\mathrm{EC}_{50}<1 \mathrm{nM}\right)$ が同定された。そのうちの1つであるJT010 (1)に着目して研究をす寸めた。非求電子性 類縁体の JT010-H は、1 と比較して〜1000 倍低い活性しかもたず、求電子性が活性に重 要であることが示された。1 は他の TRP チャネル（TRPV1、V3、V4、M2、M8、C5） を活性せず、TRPA1 に選択的であった。

【新規アゴニストの作用機序】 求電子性アゴニスト 1 の作用機序を明らかにするた め、ビオチン化誘導体 JT010-B (3)を設計・合成した。3 は細胞に発現したTRPA1 を量 依存的にビオチン化し、このビオチン化は 1 を加えることで競争的に抑えられた。以上の 結果は、 1 と 3 が共通寸る修飾サイトを介して TRPA1 に結合していることを示唆してい る。

活性化に重要と考えられている6個のシステインをそれぞれセリンに置換した変異体 を作成し解析したところ、C621S 変異体のみ 3 によってビオチン化されなかった。また、 C621S 変異体は 1 と 3 によるチャネル活性化に抵抗性を示した。これらの結果は、 1 と 3 の主要な修飾サイトが Cys621 であることを示している。

【電子顕微鏡による TRPA1 とアゴニストの複合体の観察】精製した TRPA1 四量体 と $\mathbf{3}$ の複合体を電子顕微鏡で観察した。TRPA1 は化合物依存的にアビジンーゴールドナ ノパーティクルと結合し、また、その結合位置は細胞質側であると推定された。この結果 は、これまでに報告されている Cys621の位置（細胞質）と一致する。

【結論】 1657 個の求電子性化合物のスクリーニングにより、強力かつ選択的な TRPA1アゴニストである JT010 を同定した。JT010 の作用機序を調べたところ、このア ゴニストは Cys621 を選択的に修飾することでTRPA1 を活性化していることが明らかと なった。この結果は、TRPA1 の活性化にとって、Cys621 の修飾が十分であることを示唆 している。本化合物はAITC と比較して、低濃度でサイト選択的に TRPA1 一結合するこ とから、新たなTRPA1 研究ツールとして活性化メカニズムの詳細な解明への貢献が期待 される。
（論文審査の結果の要旨）

Transient receptor potential （TRP）ファミリーに属する TRPA1 チャネル は、化学物質センサーの一つとして知られる。このチャネルは、多様な反応性 化合物によって活性化を受け、痛み、咳、呼吸パターンの変化などの防衛反応 を起こす。本チャネルは新たな鎮痛剤の創薬ターゲットでもあり、その活性化機構の 詳細な解明は重要な課題である。申請者は、1,600 を超える化合物ライブラリーから、強 力かつ選択的に TRPA1 を活性化する新規アゴニストJT010を同定した。新規アゴニスト の誘導体を用いた種々の実験により、本アゴニストの作用機序が TRPA1 の Cys621 のの 選択的な修飾を介したものであることが明らかとなった。この結果は、Cys621 への修飾 が TRPA1 の活性化に十分であること示唆する。また、申請者は、ビオチン化誘導体 JT010-B と TRPA1 の複合体を電子顕微鏡によって解析することで、結合位置が TRPA1 チャネルの細胞質側の領域であることを示した。この結果は、アゴニストと TRPA1 チャ ネルの複合体における修飾部位（Cys621）の位置情報を与えた。

以上の研究は、TRPA1 の新規研究ツール開発に貢献し、ヒトの痛みセンサーである TRPA1 チャネルの活性化メカニズムの解明に寄与するところが多い。

したがって、本論文博士（医学）の学位論文として価值あるものと認める。

なお、本学位授与申請者は、平成 28 年 2 月 19 日実施の論文内容とそれに関連した試 問を受け、合格と認められたものである。 